\title{
PENGARUH KUALITAS PELAYANAN TERHADAP KEPUASAN PASIEN RAWAT INAP DI RSUD GUNUNG TUA KECAMTAN PORTIBI KABUPATEN PADANG LAWAS UTARA
}

\author{
Rodame Monitorir Napitupulu1, Winda Hartina Harahap², Ikhwanuddin Harahap3 \\ Institut Agama Islam Negeri Padangsidimpuan \\ Jalan T. Rizal Nurdin Km. 4,5 Sihitang, Padangsidimpuan \\ E-mail: napitupulurm@gmail.com ${ }^{1}$
}

\begin{abstract}
Abstrak,
Latar belakang masalah dalam penelitian ini adalah kurangnya kualitas pelayanan RSUD Gunung Tua yang menyebabkan terdapat keluhan masyarakat sehingga kepuasan tidak terpenuhi. Fenomena masalah tersebut terdapat pada berita "Harian Analisa" menunjukkan kualitas pelayanan yang diberikan RSUD kurang baik termasuk diantaranya ketersediaan obat bagi pasien. Tujuan penelitian ini adalah untuk mengetahui pengaruh kualitas pelayanan terhadap kepuasan pasien rawat inap di RSUD Gunung Tua Kecamatan Portibi Kabupaten Padang Lawas Utara. Penelitian ini merupakan penelitian kuantitatif. Sumber data yang digunakan adalah data primer dengan teknik pengumpulan data observasi dan kuesioner (angket) dengan jumlah sampel 100 pasien. Alat analisis menggunakan alat bantu komputer dengan menggunkan program SPSS (Statistical Product And Service Solution) versi 23. Teknik analisis data yang digunakan dengan metode uji normalitas, uji linearitas, uji regresi linear sederhana, uji koefisien determinasi $\mathrm{R}^{2}$, dan uji parsial (uji $\mathrm{t}$ ). Hasil penelitan diperoleh $\mathrm{R}$ square sebesar 0,196 atau 19,6\% yang berarti variabel kepuasan pasien dapat dijeaskan oleh variabel kualitas pelayanan sebesar 19,6\% sedangkan sisanya sebesar 80,4\% dijelaskan oleh faktor-faktor lain yang tidak dibahas dalam penelitian ini. Adapun hasil penelitian dari uji parsial (uji t) menunjukkan bahwa kualitas pelayanan berpengaruh terhadap kepuasan pasien rawat inap yang dibuktikan dengan $t_{\text {hitung }}>t_{\text {tabel }}$ $(4,881>1,660)$.
\end{abstract}

Kata kunci: Kualitas Pelayanan, Kepuasan Pasien, Rumah Sakit

\begin{abstract}
,
The background of the problem in this study was the lack of quality of services at Gunung Tua Hospital which caused community complaints that satisfaction was not fulfilled. The phenomenon of the problem found in the news "Harian Analisa" shows that the quality of services provided by hospitals is not good, including the availability of medicines for patients. The purpose of this study was to determine the effect of service quality on inpatient satisfaction at Gunung Tua Hospital, Portibi District, North Padang Lawas Regency. This research is quantitative research. The data sources used are primary data with observation data collection techniques and questionnaires (questionnaires) with a sample size of 100 patients. The analytical tool uses computer aids by using the SPSS program (Statistical Product And Service Solution) version 23. Data analysis techniques are used with the normality test method, linearity test, simple linear regression test, determination coefficient test $R 2$, and partial test ( $t$ test). The research results obtained $R$ square of 0.196 or $19.6 \%$, which means that the variable patient satisfaction can be explained by the variable quality of service by $19.6 \%$ while the remaining $80.4 \%$ is explained by other factors not discussed in this study. The results of the research from the partial test ( $t$ test) showed that the quality of service had an effect on the satisfaction of inpatients as evidenced by tcount $>$ t table (4.881> 1.660).
\end{abstract}

Keywords: Service Quality, Satisfaction Patient, Hospital 


\section{PENDAHULUAN}

Kepuasan merupakan perasaan senang dan kecewa seseorang yang muncul setelah membandingkan kinerja (hasil) yang diperkirakan terhadap kinerja (hasil) yang diharapkan. Jika kinerja berada dibawah harapan, pelanggan tidak puas. Jika kinerja memenuhi harapan, pelanggan puas. Jika kinerja melebihi harapan, pelanggan amat puas atau senang (Kotler dan Keller, 2007).

Semakin berkembangnya masalah kebutuhan pokok yang harus dipenuhi masyarakat diantaranya adalah masalah kesehatan. Semua orang menginginkan kesehatan karena dinilai sangat berharga dan mahal. Kesehatan merupakan keadaan sejahtera dari fisik, mental dan sosial yang memungkinkan setiap orang hidup produktif secara sosial dan ekonomi (UU No. 3 Tahun 1992 tentang Kesehatan) (Sumiati, 2009). Dengan demikian perlu dilakukan upaya yang mendukung kesehatan bagi semua orang, salah satunya adalah pemerintah memberikan sarana kesehatan bagi masyarakatnya yang membutuhkan, dalam hal ini adalah rumah sakit. Dimana rumah sakit tersebut harus mampu memberikan kepuasan bagi pasien yang berobat. Dengan cara memberikan pelayanan yang sesuai dengan harapan dan persepsi pasien.

Keharusan memberikan pelayanan secara profesional kepada pasien ternyata juga menjadi suatu kewajiban yang harus dipenuhi penyedia jasa pelayanan dan hal itu diatur dalam Undang-Undang No. 8 Tahun 1999 tentang perlindungan konsumen atau pasien. Kewajiban menjadikan staf pelayanan mampu memberikan pelayanan secara profesional kepada pasien juga merupakan tuntunan yang tidak mudah untuk dipenuhi, apabila suatu jasa pelayanan tidak dengan segera merintisnya (Kirom, 2016).

Ajaran Islam tentang kesehatan berpedoman pada prinsip pencegahan lebih diutamakan daripada penyembuhan dalam bahasa arab prinsip ini berbunyi, al-wiqayah khair min al-ilaj. Berkenaan dengan konteks kesehatan ini ditemukan sekian banyak petunjuk kitab suci dan sunnah Nabi SAW yang pada dasarnya mengarah pada upaya pencegahan (Nata, 2002).

Rumah sakit merupakan sarana kesehatan yang menyelenggarakan pelayanan kesehatan secara merata, dengan mengutamakan upaya penyembuhan penyakit dan pemulihan kesehatan, yang dilaksanakan secara serasi dan terpadu dengan upaya peningkatan kesehatan dan pencegahan penyakit dalam suatu tatanan rujukan, serta dapat dimanfaatkan untuk pendidikan tenaga dan penelitian. Sedangkan Rumah Sakit Umum (RSU) adalah rumah sakit yang menyelenggarakan pelayanan kesehatan kepada masyarakat untuk semua jenis penyakit, mulai dari kesehatan pelayanan dasar sampai pelayanan subspesialistis sesuai dengan kemampuannya (Hartono, 2010). 
Seperti dalam Harian Analisa, Jumat 19 Mei 2017 dengan judul berita "Pelayanan Buruk, Bupati Sidak RSUD Gunung Tua”. Bupati Padang Lawas Utara (Paluta) Bachrum Harahap melakukan inspeksi mendadak (sidak) ke Rumah Sakit Umum Daerah (RSUD) Gunung Tua, Rabu 17 Mei 2017. Sidak tersebut akibat aduan dan keluhan masyarakat terkait buruknya pelayanan kesehatan di Rumah Sakit Umum Daerah (RSUD) Gunung Tua kepada Bupati Padang Lawas Utara (Paluta) Bachrum Harahap. Bupati mengatakan banyak menerima keluhan masyarakat terkait pelayanan kesehatan, termasuk ketersediaan obat bagi pasien yang berobat (Harian Analisa, diakses 23 November 2017 pukul 11.45 WIB).

Dalam Metro Online.co, 29 Juli 2018 dengan judul berita "RSUD Gunung Tua di Aek Haruaya Paluta Urgent Alkes Medis”. Dalam menangani pasien yang kondisinya kritis petugas RSUD terkesan lamban. Seorang pasien korban kecelakaan yang dilarikan ke RSUD kondisinya justru semakin parah. Menurut penjelasan Darwin Siregar ayah kandung pasien korban kecelakaan yang bernama Abdillah, awalnya pihak RSUD telah melakukan penanganan medis. Namun, dokter yang sedang tugas piket mengatakan bahwa pasien tersebut belum bisa dirawat mengingat alat potret untung mengambil gambar bagian dalam tubuh atau alat-alat kesehatan medis lainnya saat ini rusak sehingga korban harus dirujuk ke RSUD lain. Menanggapi hal itu, direktur RSUD, dr. Juliana Nasution melalui kepala TU RSUD Ganti Paruntungan SKN mengatakan, alat-alat medis seperti Rontgen dan lainlainnya sedang rusak tapi sudah di ajukan ke pemkab. Lebih lanjut, kepala TU RSUD Ganti Paruntungan, alat kesehatan seperti Rontgen di RSUD sudah lama rusak dan untuk pasien yang mau dirontgen harus ada rujukan untuk dibawa ke RSUD lain itupun jumlah pasien yang dirujuk harus berjumlah 3 orang. Jika masih 1 orang pasien belum bisa diberangkatkan, terpaksa menunggu pasien lainnya.

Dengan demikian, kejadian tersebut tentu membuat pasien merasa tidak puas terhadap rumah sakit tempat mereka dirawat. Untuk itu para pegawai rumah sakit harus meningkatkan profesionalismenya dalam menjalankan tugasnya untuk memberikan pelayanan yang terbaik dan berkualitas kepada pasien sehingga pasien dan keluarganya merasa puas. Oleh karena itulah penelitian ini menjadi penting untuk dilakukan.

\section{TINJAUAN TEORITIK}

Pada dasarnya kepuasan adalah fungsi dari harapan dan persepsi terhadap kinerja suatu produk, setelah pengunjung mendapatakan atau menggunakan layanan (Hurriyati, 2015). Kepuasan dapat diartikan sebagai adanya kesamaan antara kinerja dan pelayanan yang diterima dengan kinerja dan pelayanan yang diharapkan pasien. Dalam era kompetisi bisnis yang ketat seperti sekarang, kepuasan merupakan hal yang utama. Pasien diibaratkan 
sebagai raja yang harus dilayani, meskipun hal ini bukan berarti menyerahkan segalagalanya kepada pasien. Usaha memuaskan kebutuhan pasien harus dilakukan secara menguntungkan atau dengan situasi sama senang, yaitu keadaan dimana kedua belah pihak merasa puas dan tidak ada yang dirugikan (Sangadji dan Sopiah, 2013).

Ada tiga atribut pembentuk kepuasan pengguna jasa yakni: ketetapan waktu pelayanan, yaitu kemampuan karyawanan atau pegawai rumah sakit menyelesaikan pelayanan dengan waktu proses yang lebih cepat serta menanggapi keluhan pasien (Hasan, 2010). Contohnya, dokter dan perawat tepat waktu dalam melakukan pekerjaan dan keluhan yang dialami pasien tersebut; kesopanan dan keramahan dalam memberikan pelayanan, yaitu dokter harus berinteraksi langsung dengan pasien serta memberikan layanan yang menyenangkan, seperti dengan penampilan, bahasa yang sopan, ramah, ceria dan lincah; tanggung jawab, yaitu pelayanan yang berkaitan dalam menangani keluhan pasien dan bebas dari kesalahan-kesalahan. Contohnya, dokter secara langsung memberikan resep kepada pasien.

\section{METODE PENELITIAN}

Penelitian ini berlokasi di Rumah Sakit Umum Daerah (RSUD) Gunung Tua di Jl. Raya Gunung Tua - Binanga KM. 6 Aek Haruaya Kecamatan Portibi Kabupaten Padang Lawas Utara. Jenis penelitian yang digunakan dalam penelitian ini adalah penelitian kuantitatif. Populasi adalah kelompok besar individu yang mempunyai karakteristik yang sama ataupun populasi adalah wilayah generasi yang terdiri dari objek atau subjek yang mempunyai kuantitas dan karakteristik tertentu yang ditetapkan oleh peneliti untuk di pelajari dan kemudian ditarik suatu kesimpulan. Adapun jumlah seluruh populasi pasien rawat inap Rumah Sakit Umum Daerah (RSUD) Gunung Tua adalah 6.123 orang (daftar pasien rawat inap dari tahun 2015 sampai Oktober 2017). Sampel adalah bagian kecil dari populasi yang diambil berdasarkan teknik tertentu sehingga dapat mewakili populasi (Juliandi, 2015). Sampel berjumlah 99 orang.

Analisis data dilakukan dengan analisis regresi sederhana yang merupakan salah satu metode untuk melakukan predisksi. Regresi linear sederhana adalah teknik meramalkan dengan memahami satu variabel terikat berdasarkan satu variabel bebas. Variabel terikat diberi notasi Y, sedangkan Variabel bebas diberi Notasi X sehingga berbentuk hubungan yang dicari adalah regresi $\mathrm{Y}$ atas $\mathrm{X}$. Analisis regresi di gunakan untuk mengetahui bagaimana pengaruh variabel independen kualitas layanan $(\mathrm{X})$ terhadap variabel dependen kepuasan pasien rawat inap (Y).

Adapun bentuk persamaan analisis regresi sederhana yang di gunakan dalam penelitian sebagai berikut (Tanjung dan Devi, 2013):

Kepuasan Pasien $=\mathrm{a}+$ bKualitas Pelayanan 
Dimana:

$\mathrm{Y}=$ Kepuasan pasien rawat inap

$\mathrm{X}=$ Kualitas Pelayanan

$\mathrm{a}=$ Konstanta

b = Koefisien Regresi

Selanjutnya dilakukan uji hipotesis dengan melihat nilai $\mathrm{R}^{2}$ dan uji $\mathrm{t}$ guna melihat pengaruh variabel kualitas pelayanan terhadap kepuasan pasien.

\section{HASIL DAN PEMBAHASAN}

Berikut adalah hasil uji validitas kualitas pelayanan :

Tabel 1.

Hasil Uji Validitas Kualitas Pelayanan

\begin{tabular}{|c|c|c|c|}
\hline $\begin{array}{c}\text { Item } \\
\text { Pertanyaan }\end{array}$ & $\mathbf{r}_{\text {hitung }}$ & $\mathbf{r}_{\text {tabel }}$ & Keterangan \\
\hline Soal 1 & 0,439 & \multirow{10}{*}{$\begin{array}{l}\text { Instrumen valid jika } r_{\text {hitung }} \\
>r_{\text {tabel }} \text { dengan } n=100 . \\
\text { Pada taraf signifikan } 10 \% \\
\text { sehinga diperoleh } r_{\text {tabel }}= \\
0,166\end{array}$} & Valid \\
\hline Soal 2 & 0,615 & & Valid \\
\hline Soal 3 & 0,655 & & Valid \\
\hline Soal 4 & 0,490 & & Valid \\
\hline Soal 5 & 0,515 & & Valid \\
\hline Soal 6 & 0,668 & & Valid \\
\hline Soal 7 & 0,579 & & Valid \\
\hline Soal 8 & 0,586 & & Valid \\
\hline Soal 9 & 0,695 & & Valid \\
\hline Soal 10 & 0,740 & & Valid \\
\hline
\end{tabular}

Sumber: Hasil output SPSS versi 23 (data diolah)

Dari hasil uji validitas kualitas pelayanan (X) dapat disimpulkan bahwa item pertanyaan item soal 1 sampai dengan item soal 10 adalah valid dengan $r_{\text {hitung }}>r_{\text {tabel }}$ dengan $\mathrm{n}=99-2=97$ jadi $\mathrm{r}_{\text {tabel }}$ sebesar 0,166.

Berikut adalah hasil uji validitas kepuasan pasien :

Tabel 2.

Hasil Uji Validitas Kepuasan Pasien

\begin{tabular}{|l|l|c|c|}
\hline Item Pertanyaan & \multicolumn{1}{|c|}{$\mathbf{r}_{\text {hitung }}$} & r tabel & Keterangan \\
\hline Soal 1 & 0,359 & & Valid \\
\cline { 1 - 2 } Soal 2 & 0,520 & & Valid \\
\hline
\end{tabular}




\begin{tabular}{|c|c|c|c|}
\hline Soal 3 & 0,450 & \multirow{8}{*}{$\begin{array}{l}\text { Instrumen valid jika } \mathrm{r}_{\text {hitung }} \\
>\mathrm{r}_{\text {tabel }} \text { dengan } \mathrm{n}=100 . \\
\text { Pada taraf signifikan } 10 \% \\
\text { sehinga diperoleh } \mathrm{r}_{\text {tabel }}= \\
0,166\end{array}$} & Valid \\
\hline Soal 4 & 0,560 & & Valid \\
\hline Soal 5 & 0,532 & & Valid \\
\hline Soal 6 & 0,488 & & Valid \\
\hline Soal 7 & 0,530 & & Valid \\
\hline Soal 8 & 0,692 & & Valid \\
\hline Soal 9 & 0,585 & & Valid \\
\hline Soal 10 & 0,646 & & Valid \\
\hline
\end{tabular}

Sumber: Hasil output SPSS versi 23 (data diolah)

Dari hasil uji validitas kepuasan pasien di atas dapat disimpulkan bahwa item pertanyaan item soal 1 sampai dengan item soal 10 adalah valid, dengan $r_{\text {hitung }}>r_{\text {tabel }}$ dengan $\mathrm{n}=99-2=97$ jadi $\mathrm{r}_{\text {tabel }}$ sebesar 0,166.

Tabel 3.

Hasil Uji Reliabilitas Kualitas Pelayanan

\begin{tabular}{|r|l|}
\hline Cronbach's Alpha & N of Items \\
\hline .798 & \\
\hline
\end{tabular}

Sumber: Hasil output SPSS versi 23 (data diolah)

Berdasarkan tabel 3 Reliability Statistics di atas dapat disimpulkan bahwa variabel kualitas pelayanan adalah reliabel dengan nilai Cronbach Alpha >0,60 atau (0,798 > 0,60).

Tebel 4.

Hasil Uji Reliabilitas Kepuasan Pasien

\begin{tabular}{|r|r|}
\hline Cronbach's Alpha & N of Items \\
\hline .701 & \\
\hline
\end{tabular}

Sumber: Hasil output SPSS versi 23 (data diolah)

Berdasarkan tabel 4 Reliability Statistics di atas dapat disimpulkan bahwa variabel kepuasan pasien adalah reliabel dengan nilai Cronbach Alpha > 0,60 atau (0,701 > 0,60).

Analisis regresi di gunakan untuk mengetahui bagaimana pengaruh variabel independen kualitas layanan (X) terhadap variabel dependen kepuasan pasien (Y) pada RSUD Gunung Tua Kecamatan Portibi Kabupaten Padang Lawas Utara.

Tabel IV.7

Hasil Uji Regresi Linear Sederhana

\begin{tabular}{|l|r|r|r|r|}
\hline & $\begin{array}{r}\text { Unstandardi } \\
\text { zed Coefficients }\end{array}$ & $\begin{array}{r}\text { Standard } \\
\text { ized } \\
\text { Coefficients }\end{array}$ & & \\
Model & $\begin{array}{r}\text { Std } \\
\text {. Error }\end{array}$ & Beta & t & ig. \\
\hline
\end{tabular}




\begin{tabular}{|c|c|c|c|c|c|}
\hline$\overline{\text { (Constant) }}$ & 22. & 2.6 & & 8 & \\
\hline & 308 & 13 & & .537 & ooo \\
\hline Kualitas_Pela & .35 & .07 & & & \\
\hline yanan & 7 & 3 & .444 & .886 & Ooo \\
\hline
\end{tabular}

Sumber: Hasil output SPSS versi 23 (data diolah)

Berdasarkan tabel di atas dapat diketahui nilai konstanta adalah sebesar 22,308 dan koefisien regresi kualitas pelayanan adalah 0,357 . Maka diperoleh persamaan regresi sebagai berikut:

Kepuasan pasien $=22,308+0,357$ Kualitas pelayanan

Persamaan regresi diatas dapat dijelaskan sebagai berikut:

1) Nilai konstanta sebesar 22,308 artinya apabila variabel kualitas pelayanan nilainya o, maka variabel kepuasan pasien nilainya 22,308.

2) Koefisien variabel kualitas pelayanan sebesar 0,357 artinya jika variabel kualitas pelayanan meningkat 1 satuan, maka kepuasan pasien akan mengalami penambahan sebesar 0,357 satuan. Koefisien bernilai positif jika kualitas pelayanan naik akan meningkat kepuasan pasien.

Koefisien determinasi $\left(\mathrm{R}^{2}\right)$ digunakan untuk mengetahui persentase sumbangan variabel independen $(\mathrm{X})$ terhadap variabel dependen $(\mathrm{Y})$ yang menunjukkan keragaman nilai variabel independen yang bisa dijelaskan oleh variabel dependen. Berikut hasil pengelolahan data koefisien determinasi $\left(\mathrm{R}^{2}\right)$.

\section{Tabel 5 .}

Hasil Uji Koefisien Determinasi ( $\left.\mathbf{R}^{2}\right)$

\begin{tabular}{|c|c|c|c|c|}
\hline el $\quad$ Mod & $\mathrm{R}$ & $\begin{array}{r}\mathrm{R} \\
\text { Square }\end{array}$ & $\begin{array}{l}\text { Adjuste } \\
\text { d R Square }\end{array}$ & $\begin{array}{c}\text { Std. } \\
\text { Error of the } \\
\text { Estimate }\end{array}$ \\
\hline 1 & $\begin{array}{r}.444 \\
\mathrm{a}\end{array}$ & |198. & .189 & 4.192 \\
\hline
\end{tabular}

Sumber: Hasil output SPSS versi 23 (data diolah)

Hasil uji Koefisien Determinasi dari tabel 5. diperoleh nilai o,444 menunjukkan bahwa hubungan antara kualitas pelayanan dan kepuasan pasien terdapat hubungan sebesar 0,444 yang berarti jika di interpretasikan dari tabel nilai $\mathrm{R}$, maka berada pada interpretasi dengan tingkat hubungan yang sedang. Nilai $\mathrm{R}^{2}$ sebesar 0,198 atau 19,8\% yang menjelaskan bahwa kualitas pelayanan (X) memberikan pengaruh 19,6\% terhadap kepuasan pasien (Y) 
sedangkan sisanya $80.2 \%$ dipengaruhi oleh variabel lain yang tidak diteliti dalam penelitian ini.

Uji statistik ini digunakan untuk membuktikan signifikan atau tidaknya pengaruh variabel bebas terhadap variabel tidak bebas secara individual (parsial). Sebagai dasar pengambilan keputusan dapat di gunakan kriteria pengujian sebagai berikut:

1) Jika $t_{\text {hitung }}>t_{\text {tabel, }}$ dan tingkat signifikan $<\alpha(0,1)$ maka $H_{o}$ ditolak dan $\mathrm{H}_{\mathrm{a}}$ diterima. Hal ini berarti kualitas pelayanan mempunyai pengaruh yang signifikan terhadap kepuasan pasien rawat inap.

2) Jika $t_{\text {hitung }}<t_{\text {tabel }}$ dan tingkat signifikan $>a(0,1)$ maka $H_{o}$ diterima dan $H_{a}$ ditolak. Hal ini berati pengaruh kualitas pelayanan terhadap kepuasan pasien rawat inap.

Tabel 9

Hasil Uji Parsial (uji t)

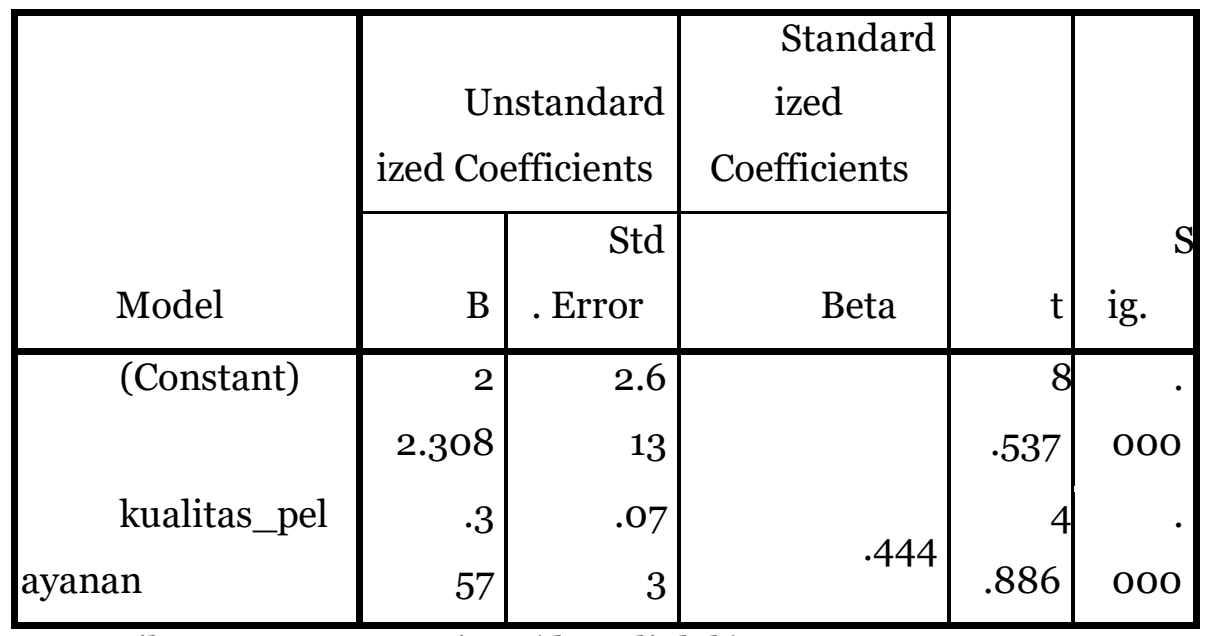

Sumber: Hasil output SPSS versi 23 (data diolah)

Dari hasil output di atas dapat dilihat bahwa thitung untuk variabel kualitas pelayanan sebesar 4,886 sedangkan $t_{\text {tabel }}$ dengan $\mathrm{df}=\mathrm{n}-2$ atau $100-2=98$ diperoleh 1,660 yang berarti $t_{\text {hitung }}>t_{\text {tabel }}(4,886>1,660)$ dan tingkat signifikan yang diperoleh $0,000<\alpha(0,1)$ maka $\mathrm{H}_{\mathrm{a}}$ diterima. Jadi dapat disimpulkan bahwa dari hasil pengujian uji parsial (uji $\mathrm{t}$ ) terdapat pengaruh kualitas pelayanan terhadap kepuasan pasien rawat inap di RSUD Gunung Tua Kecamatan Portibi Kabupaten Padang Lawas Utara.

Dari hasil penelitian didapat bahwa persamaan regresi kepuasan pasien $=22,308+$ o,357 kualitas pelayanan menunjukkan bahwa kualitas pelayanan secara keseluruhan memiliki pengaruh yang signifikan terhadap kepuasan pasien. Variabel kualitas pelayanan memiliki pengaruh yang signifikan terhadap kepuasan pelanggan sebesar 0,357\%. Dengan demikian dapat diartikan jika peningkatan terhadap kualitas pelayanan semakin baik, maka kepuasan pelanggan akan meningkat.

Berdasarkan hasil uji koefisien determinasi $\left(\mathrm{R}^{2}\right)$ menjeslakan bahwa kualitas pelayanan memberikan pengaruh 0,198 atau 19,8\% terhadap kepuasan pasien sedangkan sisanya $80,2 \%$ dipengaruhi oleh variabel lain yang tidak diteliti dalam penelitian ini. 
Kemudian berdasarkan hasil uji parsial (uji t) bahwa $t_{\text {hitung }}$ untuk variabel kualitas pelayanan sebesar 4,886 sedangkan $t_{\text {tabel }}$ adalah 1,660. Jadi dapat disimpulkan bahwa kualitas pelayanan memiliki pengaruh yang positif terhadap kepuasan pasien.

Hasil penelitian ini di dukung oleh Vinna Sri Yuniarti dalam buku "Perilaku Konsumen Teori dan Praktik" menyatakan bahwa kepuasan pasien sebagai keseluruhan sikap yang ditunjukkan pasien atas jasa setelah mereka memperoleh dan menggunakannya. Pasien yang puas akan menggunakan secara terus menerus produk dan jasa tersebut dan dengan senang hati mempromosikan produk dan jasa tersebut dari mulut ke mulut. Untuk itu RSUD Gunung Tua harus menciptakan kepuasan yang lebih tinggi dengan memberikan pelayanan yang lebih baik lagi kepada pasien dan keluarga pasien.

\section{KESIMPULAN}

Penelitian ini bertujuan untuk melihat pengaruh kualitas pelayanan terhadap kepuasan pasien rawat inap di RSUD Gunung Tua Kecamatan Portibi Kabupaten Padang Lawas Utara. Kesimpulan dari penelitian ini yaitu berdasarkan hasil penelitian yang di dukung oleh M. Nur Nasution dalam buku yang berjudul "Manajemen Jasa Terpadu" yang mengemukakan bahwa "apabila jasa yang diterima atau dirasakan (perceived service) sesuai dengan yang diharapkan, maka kualitas jasa dipersepsikan baik dan memuaskan (pasien)”. Hasil penelitian yang di dukung oleh M. Nur Nasution tersebut, belum sepenuhnya diterapkan pada RSUD Gunung Tua. Dikarenakan masih banyak pasien yang mengeluhkan kurang baiknya pelayanan yang diberikan RSUD Gunung Tua.

Hasil uji koefisien determinasi $R$ Square sebesar 0,196 atau 19,8\% hal ini menunjukkan bahwa variabel kualitas pelayanan memerikan pengaruh sebesar 19,8\% terhadap kepuasan pasien di RSUD Gunung Tua Kecamatan Portibi Kabupaten Padang Lawas Utara. Adapun dasar pengambilan keputusan ini adalah $t_{\text {tabel }}$ pada taraf signifikan 10\% sedangkan DK $=99-2=97$ sehingga diperoleh $t_{\text {tabel }} 1,660$ sementara $t_{\text {hitung }}$ sebesar 4,886. Berdasarkan $t_{\text {tabel }}$ dan $t_{\text {hitung }}$ terlihat $t_{\text {tabel }}<t_{\text {hitung }}(1,660<4,886)$ maka dapat disimpulkan $\mathrm{H}_{\mathrm{a}}$ diterima dan $\mathrm{H}_{\mathrm{o}}$ ditolak artinya terdapat pengaruh antara kualitas pelayanan terhadap kepuasan pasien rawat inap di RSUD Gunung Tua Kecamatan Portibi Kabupaten Padang Lawas Utara.

\section{DAFTAR PUSTAKA}

Ali Hasan, Marketing Bank Syariah, Bogor: Ghalia Indonesia, 2010.

Abuddin Nata, Metodologi Studi Islam Jakarta: PT Raja Grafindo Persada, 2002.

Azuar Juliandi, dkk, Metodologi Penelitian Bisnis Konsep \& Aplikasi, Medan: Umsu Press, 2015. 
Bahrul Kirom, Mengukur Kinerja Pelayanan dan Kepuasan Konsumen Edisi Revisi, Bandung: Pustaka Reka Cipta, 2016.

Bambang Hartono, Manajemen Perpustakaan Untuk Rumah Sakit, Jakarta: Rineka Cipta, 2010.

Etta Mamang Sangadji \& Sopiah, Perilaku konsumen Pendekatan Praktis Disertai Himpunan Jurnal Penelitian, Yogyakarta: Andi, 2013.

Harian Analisa, "Pelayanan Buruk, Bupati Sidak RSUD Gunungtua" http://harian. analisadaily.com/sumut/news/pelayanan-buruk-bupati-sidak-rsud gunungtua/346709/2017/05/19, diakses 23 November 2017 pukul 11.45 WIB.

Philip Kotler dan Kevin Lane Keller, Manajemen Pemasaran Edisi Kedua Belas Jilid 1, Indonesia: PT Indeks, 2007. , Manajemen Pemasaran Edisi 13 Jilid 1, Jakarta: Erlangga, 2008.

Ratin Hurriyati, Bauran Pemasaran dan Loyalitas Konsumen, Bandung: Alfabeta, 2015.

Sumiati, dkk, Kesehatan Jiwa Remaja dan Konseling, Jakarta: Trans Info Media, 2009.

Tanjung, Hendri \& Abrista Devi, Metode penelitian Ekonomi Islam Jakarta: Gramata, Publishing, 2013. 